\title{
The Avoided Cost Standard Under PURPA
}

\author{
R. J. Cole \\ I. Holmlund \\ S. A. Smith \\ T. A. Williams
}

\section{April 1983}

Prepared by Pacific Northwest Laboratory under a Related Services Agreement with the U.S. Department of Energy Contract DE-AC06-76RLO 1830

Pacific Northwest Laboratory Operated for the U.S. Department of Energy by Battelle Memorial Institute 


\title{
DISCLAIMER
}

This report was prepared as an account of work sponsored by an agency of the United States Government. Neither the United States Government nor any agency thereof, nor any of their employees, makes any warranty, express or implied, or assumes any legal liability or responsibility for the accuracy, completeness, or usefulness of any information, apparatus, product, or process disclosed, or represents that its use would not infringe privately owned rights. Reference herein to any specific commercial product, process, or service by trade name, trademark, manufacturer, or otherwise, does not necessarily constitute or imply its endorsement, recommendation, or favoring by the United States Government or any agency thereof. The views and opinions of authors expressed herein do not necessarily state or reflect those of the United States Government or any agency thereof.

\author{
PACIFIC NORTHWEST LABORATORY \\ operated by \\ BATTELLE \\ for the \\ UNITED STATES DEPARTMENT OF ENERGY \\ under Contract DE-AC06-76RLO 1830
}

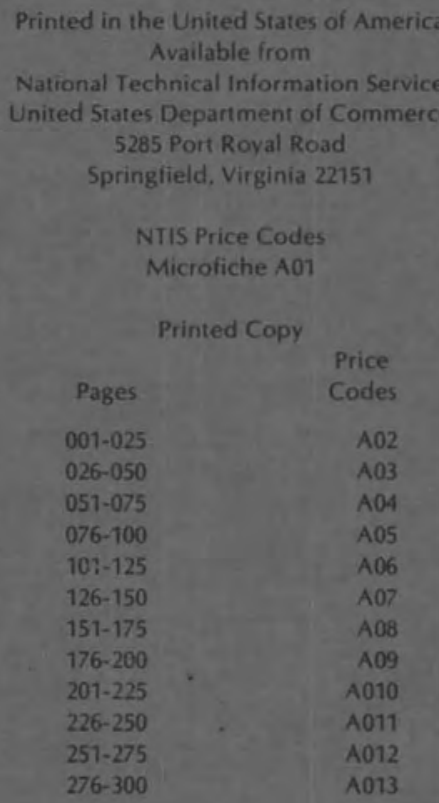


THE AVOIDED COST STANDARD UNDER PURPA

\author{
Roland J. Cole (a) \\ Ingrid Holmlund (a) \\ Steven A. Smith \\ Thomas A. Williams
}

Apri1 1983

Prepared by Pacific Northwest Laboratory under a Related Services Agreement with the U.S. Department of Energy under Contract DE-AC06-76RL0 1830

Pacific Northwest Laboratory

Richland, Washington 99352

(a) Battelle-Human Affairs Research Centers Seattle, Washington 98105 


\section{SUMMARY}

The Public Utility Regulatory Policies Act (PURPA) (P.L. 95-617) was passed to encourge electricity conservation through a variety of regulatory and rate reforms. The purpose of this paper is to provide information on the controversy surrounding the avoided cost standard established under PURPA. Promulgated by the Federal Energy Regulatory Committee (FERC) in February 1980, the avoided cost standard sets a minimum rate for utilities purchasing power from a qualified facility (QF) at the utilities full avoided cost. Recent court cases have challenged this standard and FERC is currently appealing to the Supreme Court. The impact of these court cases may have little effect on the actual rates set by state Public Utility Commissions (PUCs), which can require rates higher than the minimums established by FERC, since many PUCs appear in favor of requiring full avoided costs. The arguments for and against requiring utilities to pay full avoided costs come down to balancing between incentives for QFS on the one hand and "fairness" to utilities and their non-QF customers on the other. 


\section{CONTENTS}

\begin{tabular}{l} 
SUMMARY \\
INTRODUCTION \\
\hline
\end{tabular}


THE AVOIDED COST STANDARD UNDER PURPA

\section{INTRODUCTION}

The Public Utility Regulatory Policies Act (PURPA) (P.L. 95-617) was passed to encourage electricity conservation through a variety of regulatory and rate reforms. The purpose of this paper is to provide information on the controversy surrounding the avoided cost standard established under PURPA. The first section provides background information on the existing $1 \mathrm{aw}$, as well as an overview of the recent litigation involving the Federal Energy Regulatory Commission (FERC). Next, the results of a survey of several state procedures for establishing standard rates for Qualified Facilities (QFs) are presented. Finally, arguments for and against paying rates based on fully avoided costs are discussed.

\section{EXISTING LAW AND REGULATIONS}

The Public Utility Regulatory Policies Act (P.L. 95-617) is directed toward encouraging conservation of electricity through a variety of regulatory and rate reforms. Under a section of the Act dealing with cogeneration and small power production (Sec. 210; 16 USCA 824a-3), the Federal Energy Regulatory Commission (FERC) must prescribe rules requiring electric utilities to: "(1) sell electric energy to qualifying cogeneration facilities and qualifying small power production facilities and (2) purchase electric energy from such facilities" (Sec. 210(a); 16 USCA 824a-3(a)). (A small power production facility is defined as one that "(i) produces electric energy solely by the use, as a primary energy source, of biomass waste, renewable resources, or any combination thereof; and ( $i i)$ has a power production capacity . . not greater than 80 megawatts." To be considered a qualifying facility, a cogenerator or small power producer must be "owned by a person not primarily engaged in the generation or sale of electric power," and must meet other requirements prescribed by FERC.) 
According to PURPA, such FERC rules must follow several standards regarding rates for purchases by utilities. Rates must be "just and reasonable" to the electric consumers of the electric utility, "in the public interest," and must "not discriminate against qualifying cogenerators or qualifying small power producers." Finally, "no such rule prescribed under subsection (a) shall provide for a rate which exceeds the incremental cost to the electric utility of alternative electric energy" (Sec. 210(b); 16 USCA $824 a-3(b))$. Regarding this final provision, the Act further explains "incremental cost to the electric utility of alternative electric energy" as "the cost to the electric utility of the electric energy which, but for the purchase from such cogenerator or small power producer, such utility would generate or purchase from another source" (Sec. 210(d); 16 USCA $824 a-3(d))$. This cost standard is commonly referred to as "avoided costs."

On February 25, 1980, FERC promulgated final rules regarding Section 210. According to these rules, if the rate for a utility's purchase of electricity from a qualifying facility (QF) equals the utility's full avoided cost, it satisfies PURPA standards (18 CFR 292(b)(2)). However, FERC rules do not prevent a state regulatory authority from establishing rates for utility purchase that are higher than avoided costs, if the state's law authorizes such rates. In other words, under FERC rules, the minimum rate for utilities purchasing power from QFs is the full avoided cost (45 FR 12221, Feb. 25, 1980).

FERC rules do not limit the authority of a utility and a QF to negotiate and agree upon their own rates or terms that differ from the conditions otherwise specified by FERC (18 CFR 292.301). Therefore, QFs can choose either to subscribe to terms set by the state PUC, or to make their own agreements with utilities.

The FERC rules give state regulatory authorities considerable leeway in determining avoided costs. These state authorities (typically public utility commissions, or PUCS) are not required to apply any particular method in calculating the cost standard. However, the rules state that certain factors must "to the extent practicable, be taken into account" in order for the established avoided cost to satisfy PURPA standards (18 CFR 
292.304(e)). These factors include: data on energy and capacity costs that utilities must supply to state authorities (see 18 CFR 292.302); data on the availability of capacity or energy from a QF during system daily and seasonal peak periods; the relationship between the availability of the QF's capacity or energy and the utility's ability to avoid costs; and the comparative costs or savings resulting from the utility's line loss variations if the QF did, or did not, contribute power.

Under PURPA, state PUCs and nonregulated electric utilities were to have implemented the FERC rules on or before March 21, 1981 (Sec. 210(f); 16 USCA $824 a-3(f))$. FERC rules require that these state authorities should have begun implementation by that date with the establishment of standard rates for purchases from QFs with a design capacity of $100 \mathrm{~kW}$ or less (18 CFR 292.304(c)(1)). Such implementation could be accomplished through the issuance of regulations adopting FERC rules, application of the rules on a case-by-case basis, an undertaking to resolve disputes between QFs and utilities, or by any other action reasonably designed to apply the rules so that the authorities had set procedures and were prepared to take applications (18 CFR 292.401 and 45 FR 12231, Feb. 25, 1980). For utility purchase from QFs larger than $100 \mathrm{~kW}$, PUCs may establish standard rates, but are not required to. By the end of 1981, not all state PUCs had finished the implementation requirements; many had made significant progress toward that end, but there was wide variability in their status (Lock and Van Kuiken, pp. 660-661).

COURT CASES INVOLVING PURPA AND FERC RULES

Both PURPA and the FERC rules regarding Sec. 210 have been challenged in the federal courts in two separate cases. In the first case, the State of Mississippi sought to have Titles I and III and Title II Sec. 210 of PURPA declared unconstitutional (FERC et al. v. The State of Mississippi et al., No. 80-1749). It argued that these sections of PURPA exceeded Congressional power under the Commerce $C l$ ause and invaded state sovereignty in violaton of the Tenth Amendment. The District Court decided in favor of Mississippi on both issues. However, FERC appealed to the Supreme Court, which reversed that decision. 
The Supreme Court held that because Congress found explicitly that the regulated activities under PURPA have an immediate effect on interstate commerce, and because the congressional conclusion that federal regulation of these activities was supportable by the legislative history, the provisions were within Congress' power under the Commerce Clause. Secondly, the Court found that none of the challenged provisions violated the Tenth Amendment. Specifically regarding Sec. 210's requirement that state authorities implement FERC rules, the Court held that, since the statute and its rules simply required state commissions to settle disputes arising under the statute, there was no real difference between the kinds of adjudication the Mississippi PUC customarily performed and that which would be required under PURPA's Sec. 210 (see 50 US Law Week, 4566, 4569-4571, June 1, 1982).

While the Mississippi case ultimately did not threaten PURPA, the outcome of the second, more recent case may have a significant effect on FERC's rules regarding avoided costs. In American Electric Power Service Corporation et al. V. FERC (675 F2d, 1226 (1982)), the utility challenged four of the rules promulgated by FERC under PURPA's Sec. 210, one of which was the "full avoided cost" rule. The U.S. Court of Appeals vacated this rule and remanded it to the Commission, on the ground that FERC had failed to "justify and explain its decision to prohibit in an across-the-board manner rates below full avoided cost," particularly in view of the standards set forth by Congress in Sec. 210(b) (675 F.2d 1236).

In its decision, the Court suggested that requiring utilities to pay full avoided costs was not automatically consistent with "the clear intent of Section 210 (b), which seeks to strike a balance among the interests of cogenerators, 'electric consumers of electric utilities,' and the 'public interest'" (675 F2d 1234). The Court also indicated that Congress had made it clear that the incremental cost standard in Sec. 210(b) "is not to become a substitute for the 'just and reasonable' standard . . though the two may coincide" (675 F2d 1233). The Court stated that, "By ordering that the purchase rate be equal to the full avoided cost in every case, FERC has, without convincing explanation, simply adopted as a uniform rule the maximum purchase rate specified in the statute . . The Commission 
may be right in its conclusion, but it needs to make its reasoning and findings explicit." The Court said that, on remand, it expected FERC "to take a harder look at, especially, the percentage of avoided cost approach." It suggested that FERC might either set a certain percentage, or allow state PUCs to set rates within a range, for example, 80 to $100 \%$, of avoided costs (576 F2d 1233-34).

FERC petitioned the Court of Appeals for a rehearing, but the Court denied the petition on April 23,1982. FERC subsequently requested the Supreme Court to review the case. According to a FERC official, the Court will probably decide whether to review the case in 0ctober, 1982. If the Court does take the case, FERC expects a decision around June, 1983. Until the status of the case in the Supreme Court is determined, FERC will take no action regarding its rules. If the Court denies review, or if it ultimately decides against FERC, the agency will then face a new rulemaking procedure.

Even if FERC ultimately revises its rules, this may have little effect on PUCs' policies. For example, if FERC rules were revised to allow for setting rates within a range of percentages of avoided costs, it is likely that many PUCs that have established rates at full avoided costs would let these rates stand. For one thing, in a number of states, full avoided costs are now required by law. Furthermore, many PUCs favor the full avoided cost standard. The only PUCs that might change rates would be any that had felt bound by the original FERC rules to set their rates at the full avoided cost level, even though they believed they were too high (Lock and Van Kiuken, p. 662).

\section{STATE IMPLEMENTATION OF FERC RULES}

As noted above, FERC required PUCs to establish a standard rate for QFs of $100 \mathrm{~kW}$ or less, based on data submitted by each utility. Having accomplished this, many PUCs have proceeded with various approaches for larger QFs. Some PUCs have decided to leave these cases primarily to negotiations between $Q F s$ and utilities, with little state intervention except in cases that require arbitration of a dispute. In other states, PUCs are setting standard rates either through case-by-case adjudication 
or rulemaking. Such rates are established on a QF-specific, utilityspecific, or statewide basis.

In most states, the utility-specific approach is favored, principally because of the existence of two or more utilities with load and generation data that are disparate enough to result in substantially different avoided costs. Although the rates established in a QF-specific procedure would be designed more particularly for the individual case, and thus may be more accurate, this approach has significant disadvantages. For one thing, a PUC could face a major administrative and financial burden by having to adjudicate each case individually. Furthermore, in this approach, QFs might be dissuaded from applying, because of the costs of entering into an adjudicatory ratemaking proceeding with the utility, and because rates would be less predictable. On the other hand, while a few PUCs (such as Vermont and New Hampshire) have established statewide rates, in most states data are too specific to particular utilities to allow for the setting of accurate rates by this method (see Lock and Van Kuiken, pp. 665-666, for further discussion of these issues).

The factors that different states take into account in calculating avoided costs vary widely. While FERC rules recommend consideration of the costs and availability of both capacity and energy to the extent practicable, most PUCs have focused on the energy rate, usually using some short-run, marginal cost approach. A state's emphasis on the energy rate is likely due to heavy reliance on expensive fuels, or its utilities currently having great excess capacity. Besides these reasons, as FERC has acknowledged, the capacity credit for a $Q F$ is difficult to calculate because it involves forecasting of future occurrences in the utility and the QF. Yet, some PUCs have undertaken either generic or utility-specific methods to determine capacity credits, of ten establishing special criteria to aid in their calculations. For example, Oklahoma has made different assumptions about the efficiency of various energy sources, including wind, hydropower, and photovoltaics, in order to calculate standard avoided costs that take capacity into account for each of these sources. Other PUCs, such as California, have factored the length of the contract 
between the utility and the QF into their capacity calculations (see Lock and Van Kuiken, pp. 672-673).

Some states have also figured the time of use of QF power into their calculations. A number of states, such as California, have set time-of-day rate structures reflecting whether the energy is provided by the QF during peak periods or off-peak periods. Other states, such as Illinois, have also considered seasonal as well as daily peak periods in their calculation methods. While such attention to the time of use of QF power would add greater precision to the calculation of avoided costs, it can also create additional monitoring and administrative costs, which may be prohibitive (see Lock and Van Kuiken, p. 673, and 45 CFR 12226).

\section{SELECTED STATE PROGRAMS}

In order to ascertain current attitudes and approaches taken by PUCS toward the establishment of rates and the avoided costs issue, we spoke to representatives of several state commissions. The data from those interviews is summarized in Table 1 at the end of this section.

\section{Arizona}

According to a spokesman for the Arizona Corporation Commission's Utilities Division, the agency generally favors FERC's avoided costs rules and its guidelines for establishing rates. For utility purchase of power from QFs with a design capacity of less than $100 \mathrm{~kW}$, utilities file information on their avoided costs with the commission, which approves standard rates based on these data. Utilities must file updated data every three months because of high variability in fuel costs, and the commission revises the standard rates accordingly. Rates for facilities over $100 \mathrm{~kW}$ are left to negotiation between the QF and the utility. However, the commission must approve the final contract. In addition, the commission may become involved as an arbitrator in the case of a contract dispute.

Avoided costs are comparatively low in Arizona, because the source of more than half of the power generation is coal. So far there has been 
very little need to implement the cogeneration and small power production program in the state.

As for whether any changes in FERC rules on avoided costs would affect the state's policies, the spokesman said that if FERC set a fixed percentage of full avoided costs, or allowed for a range of percentages, Arizona would at least reconsider its current practices, especially if utilities made an issue of it. It is not clear, however, whether the state would actually change its current policy.

\section{California}

In California, the PUC requires utilities to purchase power at standard rates that it has established and revises periodically. These rates are utility-specific, based on each utility's full avoided costs. The rates do not differ according to the size of the QF. Because the avoided costs are based on the marginal costs of oil-fired plants, they are relatively high. As mentioned above, the state also applies the time-of-day concept to its rate requirements, and makes its capacity credit calculations dependent on the length of the contract between the QF and the utility.

California is a strong advocate of the full avoided cost requirement as an incentive to alternative energy production. The establishment of rates at full avoided costs is mandated by state law. Therefore, any revision in FERC rules regarding avoided costs would not alter the state's current policy.

\section{New Mexico}

In New Mexico, standard rates for QFs less than $100 \mathrm{~kW}$ are established based on avoided cost data submitted by utilities, and revised annually. Regarding QFs greater than $100 \mathrm{~kW}$, no rates are established. The state PUC requires utilities to negotiate on a case-by-case basis with QFs. However, the PUC exercises considerable monitoring authority over the negotiations, and attaches certain conditions to the contracts. The foundation for negotiations must be the utility's full avoided costs, with adjustments for individual characteristics. The utility must provide data 
related to its calculations of avoided costs upon the request of the PUC. Furthermore, contracts in which utilities pay QFs more than full avoided costs are not allowed. Utilities must file all contracts with the PUC for approval (Lock and Van Kuiken, pp. 676-677).

Since no contracts have yet been filed with the PUC, it has little practical experience on which to base a judgment of its program. However, a PUC spokesman said that the state generally agrees with the full avoided cost standard, and wants to encourage small power production facilities.

\section{Washington}

In Washington, utilities must file data annually with the PUC on their projected avoided costs during peak and off-peak periods for the current year and each of the next five years. They also must file their capacity plans and costs for each year in the next ten years. For purchases from QFs less than $100 \mathrm{~kW}$, utilities must establish a standard rate based on their avoided costs. Regarding the procedure for larger QFs, the utility and the QF negotiate their own rates, and need not submit their contract to the PUC. However, like the FERC rules, Washington rules require that these rates must equal the avoided costs in order to satisfy PURPA. If there is a dispute in contract negotiation, the parties may appeal to the PUC for arbitration.

According to a PUC spokesman, avoided costs are extremely low in Washington due to the fact that they are calculated based on an average of the state's years of reliance on hydroelectric power. Further, these established avoided costs have decreased drastically in the past year, so that prospective small QFs are deterred from entering the market, and existing ones are having difficulties.

ARGUMENTS FOR AND AGAINST PAYING FULL AVOIDED COSTS

Alternatives to Paying Full Avoided Cost

Understanding arguments for and against paying full avoided costs requires knowledge of alternative approaches for determining rates for QFs. When the FERC rules were being considered, a "split-the-savings" 
TABLE 1. Summary of State PUC Approaches for Establishing Rates for QFs

\begin{tabular}{lc} 
& Rate Base \\
\hline QFs & QFs \\
$<100 \mathrm{KW}$ & $>100 \mathrm{KW}$
\end{tabular}

$\begin{array}{ll}\text { Data } & \text { Major Form } \\ \text { Revision } & \text { of Power } \\ \text { Requirements } & \text { Generation }\end{array}$

Comments

\begin{tabular}{|c|c|c|c|c|c|}
\hline Washington & $\begin{array}{l}\text { Full avoided } \\
\text { costs }\end{array}$ & Negotiated & Annually & Hydroelectric & $\begin{array}{l}\text { Avoided costs extremely low; } \\
\text { rates must equal avoided costs } \\
\text { in order to satisfy PURPA }\end{array}$ \\
\hline
\end{tabular}


approach was suggested, in which utilities and QFs would share the difference between the full avoided cost and the QF's generating cost. However, there were several problems with this approach. For one thing, this method would require an examination of QFS' production costs. Besides the fact that this would create an even greater administrative burden, many contend that this would violate the intent of PURPA, which is to exempt QFs from cost-of-service regulation. Some had argued that providing utilities with a fraction of the savings would promote their cooperation. However, FERC argued that enough indirect benefits were already available to utilities in the small power production and cogeneration arrangements that additional incentives were unnecessary.

Another possibility is to retain the avoided cost concept, but to establish rates based on some percentage of full avoided costs. Some utilities favor the setting of rates at a fixed percentage of avoided costs, such as $90 \%$, to prevent subsidization of QFs. However, QFs and most PUCS argue that this would amount to a disincentive for QF investment in cogeneration and small power production.

\section{Arguments For Paying Full Avoided Costs}

The arguments for paying full avoided costs center around the incentive effects for cogenerators and small power producers.

1. Requiring the full amount allowed by PURPA maximizes the incentive to the developer of a qualifying facility.

2. Since these facilities produce small amounts of power by definition, they would have a minimal impact on the rate base of the utility. Rate reductions for individuals resulting from an allocation of part of the savings from small power production to ratepayers would be an insignificant incentive compared to the incentive for growth of small power production that might result if the savings were allocated to the relatively small number of QFs.

3. This system puts the burden of estimating the price on the already-regulated utility, instead of the QF, as Congress 
intended. Many other schemes, notably any kind of "split the savings approach," require detailed accounting from the $Q F$, and Congress specifically directed that the regulatory path be eased for QF developers.

4. Utilities are monopsonists (i.e., the sole buyer of the power produced) with respect to QFs, and small power producers are likely to lack significant resources for negotiation. Therefore a set rate (rather than a range) is needed to head off dramatically unequal bargaining.

5. Furthermore, even though full avoided costs would not provide rate savings to customers, in the long run, these ratepayers and the nation would benefit from decreased reliance on scarce fuels.

6. In the short-run, this requirement may increase rates. However, in the long-run, there may be rate savings since the power generated by cogenerators and small producers could offset a utility's need to add capacity.

Arguments Against Paying Full Avoided Costs

The arguments against paying full avoided costs, other than strictly legal ones (such as FERC did not adequately justify its decision) center around effects on utilities and utility customers.

1. This power is less valuable than the power that might be produced by utilities.

a. It is apt to be a newer technology and thus more risky.

b. Since it is outside the control of the utility, it contributes less to utility flexibility in meeting shifting power loads.

c. Depending on the utility commission, a QF may be outside the rate base, so the utility recovers only its cost, rather than a return on the facility, as it would if it owned the facility.

2. Slightly less than full avoided cost (e.g., 90\%) would actually increase the total incentive, because the utility and its 
customers, as well as the QF developer, would have an incentive to be involved.

3. Monopsony is less relevant because the utility is already required to buy the power when and where it is offered.

4. QF developers may not need full avoided costs because they are subject to less stringent poliution controls or pay lower taxes.

5. Although "splitting the savings" would add to the accounting burden of QFs, many other schemes, such as $90 \%$ full avoided cost, would not.

6. Although any individual QF has a small effect on rates, cumulatively the payment of full avoided cost may increase the costs of power for everyone but the QF developers. Also, unless utilities are able to purchase power from QFs at a rate less than avoided costs, they and their ratepayers will be subject to the increasing price of $0 i 1$.

7. The complexity and variability of avoided cost calculations would make rates unpredictable, and thus QFs might be prevented from investing because of the attendant risks. (However, as PUCs have gained more experience with the calculations, and as patterns of rates have become apparent in each state, uncertainty is diminishing and the outlook for investment seems to be stabilizing. Furthermore, PUCs argue that flexibility in their proceedings is necessary to apply state-specific conditions in their calculations.)

8. PUCs might attempt to subsidize QFs covertly by establishing methodologies for avoided cost calculations that will result in high rates for utility purchase. (However, utilities should be able to counteract any PUC attempts at covert subsidization, because they have the data used in the PUCs' calculations, and the capability to analyze the methods PUCs are using. In addition, if PUCs regularly review rates to keep up with changes in avoided costs, they should be able to guard against rates 
that may unintentionally result in unfair subsidies (see Lock and Van Kiuken, p. 669).)

\section{CONCLUSION}

The existing status of full avoided cost under PURPA can be summarized as follows:

1. The federal requirement that QFs must be paid full avoided cost and the states must establish explicit rates for QFs under 100 $\mathrm{kW}$ is on hold. The Court of Appeals has thrown out the FERC rule, and FERC is appealing to the Supreme Court.

2. In the meantime, several states have adopted their own rule to the same effect, often applying even to QFs 1 arger than $100 \mathrm{~kW}$. Some of them indicated that they were likely to retain the state rule, even if the FERC rule was never reinstated.

3. The arguments for and against requiring utilities to pay full avoided cost come down to a balancing between incentives for QFS on the one hand and "fairness" to utilities and their non-QF customers on the other. Most states have resolved the balance in favor of incentives for QFs. 


\section{References}

\section{Statute}

Public Utility Regulatory Policies Act, P.L. 95-617.

\section{Regulations}

"Small Power Production and Cogeneration Facilities; Regulations Implementing Section 210 of the Public Utility Regulatory Policies Act of 1978," 45 FR 12214 et seq. Feb. 25, 1980.

\section{Court Cases}

American Electric Power Service Corporation et al., v. FERC. No. 80-1789, 675 F.2d 1226 (1982).

FERC v. Mississippi. No. 80-1749. $50 \mathrm{LW} \mathrm{4566.} \mathrm{June} \mathrm{1,} 1982$.

\section{Law Review Articles}

Lock, Reiner H.J.H. "Encouraging Decentralized Generation of Electricity: Implementation of the New Statutory Scheme." 2 Solar Law Reporter 705, Nov./Dec. 1980.

Lock, Reiner H.J.H. and Jack C. Van Kuiken. "Cogeneration and Small Power Production: State Implementation of Section 210 of PURPA." 3 Solar Law Reporter 659, Nov./Dec. 1981. 


\section{DISTRIBUTION}

No. of

Copies

OFFSITE

J. B. Woodard

Division 8454

Sandia National Laboratory

Livermore, CA 94550

A. C. Skinrood

Division 8452

Sandia National Laboratory

Livermore, CA 94550

J. B. Wright

Division 8450

Sandia National Laboratory

Livermore, CA 94550

W. G. Wilson

Division 8453

Sandia National Laboratory

Livermore, CA 94550

H. F. Norris

Division 8452

Sandia National Laboratory

Livermore, CA 94550

W. C. Peila

Division 8453

Sandia National Laboratory

Livermore, CA 94550

T. A. Williams

Division 8454

Sandia National Laboratory

Livermore, CA 94550

G. W. Braun

U.S. Department of Energy

Div. of Solar Thermal Technology

Forrestal Building, Rm. 5H021 I

Code CE-314

1000 Independence Ave., S.W.

Washington, D.C. 20585
No. of

Copies

OFFSITE

C. B. McFarland

U.S. Department of Energy

Div. of Solar Thermal Technology

Forrestal Building, Rm 5H02lI

Code CE-314

1000 Independence Ave., S.W.

Washington, D.C. 20585

M. R. Scheve

U.S. Department of Energy

Div. of Solar Thermal Technology

Forrestal Building, Rm 5H021I

Code CE-314

1000 Independence Ave., S.W.

Washington, D.C. 20585

K. T. Cherian

U.S. Department of Energy

Div. of Solar Thermal Technology

Forrestal Building, Rm 5H021I

Code CE-314

1000 Independence Ave., S.W.

Washington, D.C. 20585

G. N. Pappas

U.S. Department of Energy

Albuquerque Operations Office

Special Programs Division

P0 Box 5400

Albuquerque, NM 87115

T. F. Heenan

U.S. Department of Energy

San Francisco Operations Office

1333 Broadway

Oakland, CA 94612

R. W. Hughey

U.S. Department of Energy

San Francisco Operations Office

1333 Broadway

Oakland, CA 94612 
No. of

Copies

$\underline{\text { OFFSITE }}$

V. C. Truscello

Jet Propulsion Laboratory 4800 0ak Grove Drive

Pasadena, CA 91103

E. S. Davis

Jet Propulsion Laboratory

4800 0ak Grove Drive

Pasadena, CA 91103

H. Habib-agahi

Jet Propulsion Laboratory

4800 0ak Grove Drive

Pasadena, CA 91103

J. Bigger

EPRI

P0 Box 10412

3412 Hillview Avenue

Palo Alto, CA 94303

E. A. DeMeo

EPRI

P0 Box 10412

3412 Hillview Avenue

Palo Alto, CA 94303

B. Gupta

SERI

1617 Cole Boulevard

Golden, C0 80401

K. 01sen

SERI

1617 Cole Boulevard

Golden, C0 80401

B. Butler

SERI

1617 Cole Boulevard

Golden, C0 80401
No. of

Copies

OFFSITE

A. Z. Ullman

Energy Systems Corp.

Rockwell International

8900 De Soto Avenue

Canoga Park, CA 91304

Eric R. Weber

Arizona Public Service Company

PO Box 21666

Phoenix, AZ 85036

George St. John

AMFAC Energy, Inc.

PO Box 3230

Honolulu, HI 96801

James E. Brown

El Paso Electric Company

PO Box 982

El Paso, TX 79960

Ted Fick

Bechtel Group, Inc.

50 Beale Street

San Francisco, CA 94119

Keith Rose

U.S. Department of Energy

San Francisco Operations Office 1333 Broadway

Oakland, CA 94612

B. L. Broussard

Arizona Public Service Company

P0 Box 21666

Phoenix, AZ 85036

K. G. Davidson

Gas Research Institute

8600 West Bryn Mawr Avenue

Chicago, IL 60731 
No. of

Copies

OFFSITE

J. C. Grosskreutz

Black \& Veatch Consulting Engrs. P0 Box 8450

Kansas City, MO 64114

D. Martin

University of Kansas Center for Research

2291 Irving Hill Drive

Lawrence, KS 66045

D. Schieffel

ARCO Ventures Company

515 South Flower Street

Los Angeles, CA 90071

T. H. Springer

Rockwell International

Energy Systems Group

8900 De Soto Avenue

Canoga Park, CA 91304

C. La Porta

4618 Nottingham Drive

Chevy Chase, MD 20815

E. Ney

Georgia Power Company

7 Solar Circle

Shenandoah, GA 30265

J. S. Bichler

Central Solar Energy Res. Corp

1200 Sixth Street

358 Executive Plaza

Detroit, MI 48226

P. Mathur

Aerospace Corporation

PO Box 92957

Los Angeles, CA 90009

J. Yudelson

Solar Initiative

162 Christen Drive

Pacheco, CA 94553
No. of

Copies

OFFSITE

S. Biddle

Renewable Energy News

PO Box 38

Spinnerstown, PA 18968

J. Grissett

C. B. Day Co., Inc.

2751 Buford Hwy. N.E.

Atlanta, GA 30324

H. Seielstad

Pacific Gas \& Electric 3400 Crow Canyon Rd.

San Ramon, CA 94583

J. Montague

Martin Marietta Corp.

PO Box 179

Denver, C0 80201

K. Feng

U.S. GAO, LA Regional Office

World Trade Center, Suite 1010

350 S. Figueroa Street

Los Angeles, CA 90071

A. Jenkins

Cal ifornia Energy Commission

1516 Ninth Street

Sacramento, CA 95814

P. Bos

Polydyne, Inc.

1230 Sharon Park Dr.

Suite 61

Menlo Park, CA 94025

H. Morse

Acurex Solar Corp.

485 Clyde Ave.

Mountain View, CA 94042

G. Hutchinson

Solar Kinetics, Inc.

8120 Chancell or Row

Dallas, TX 75247 
No. of

Copies

$\underline{\text { OFFSITE }}$

L. Katz

American University

327 Letts $\mathrm{Hall}$

Washington, D.C. 20016

S. D. Elliot

U.S. Department of Energy

Solar Energy Division

PO Box 366

Daggett, CA 92327

R. Gervais

McDonnell Douglas Astronautics Co. 5301 Bolsa Ave.

Huntington Beach, CA 92647

R. Hallet

McDonnel1 Douglas Astronautics Co.

5301 Bolsa Ave.

Huntington Beach, CA 92647

J. Raetz

McDonnell Douglas Astronautics Company

5301 Bolsa Ave.

Huntington Beach, CA 92647

J. Roland

McDonnell Douglas Astronautics Co.

5301 Bolsa Ave.

Huntington Beach, CA 92647

J. N. Reeves

Southern California Edison

PO Box 800

Rosemead, CA 91770

P. E. Skvarna

Souther California Edison

P0 Box 366

Daggett, CA 92327
No. of

Copies

ONSITE

27 DOE Technical Information Center

DOE Richland Operations office

H. E. Ransom

R. K. Stewart

23 Pacific Northwest Laboratory

W. B. Ashton

C. H. Bloomster

D. R. Brown (5)

J. A. Dirks

K. Drumheller

B. A. Garrett-Price

H. Harty

S. A. Smith

L. D. Williams

Economics Library (3)

Technical Information (5)

Publishing Coordination (2)

9 Human Affairs Research Centers

R. Cole (5)

P. Sommers

I. Holmlund

S. Malhotra

H. Edlehertz 